\title{
Political Rituals and Popular Politicization in Imperial Brazil
}

DOI

$h+t p / / / d x d o$ iorg/10 1590/2236-463320150902

\section{Hendrik Kraay ${ }^{1}$}

Professor at the University of

Calgary (Calgary-Alberta / Canadá)

e-mail: kraay@ucalgary.ca

\begin{abstract}
This article compares the mechanisms of popular politicization in nineteenth-century France and Brazil, in light of the innovative approaches of Emmanuel Fureix, presented at Almanack's forum on 26 August 2014, and published as an article in this issue. Fureix analyzes rites of protest in France from the 1820s to the 1840s and suggests that opposition funerals, political banquets, and charivaris were part of a process of predemocratic politicization. Although it is easy to identify similar practices in nineteenth-century Brazil, they did not lead to a more democratic or "modern" politics in the second half of the century.
\end{abstract}

\section{Keywords}

civic rituals, popular politics, citizenship, Brazilian empire, politicization 
MACEDO, Joaquim Manoel de. A carteira de meu tio. Rio de Janeiro: Emp. Typ. Dous de Dezembro, 1855. p. $67,1^{\circ}$ folheto.
In his satire of the Conciliação (Conciliation period), A carteira do meu tio (My Uncle's Notebook, 1855), Joaquim Manoel de Macedo recounts the story of a "poor devil" whom the narrator meets on the rough Estrada Real (Royal Road). The citizen "has three rights: to be a National Guardsman, a jury member, and to vote in first-round elections; but when he misses a patrol or a parade he is the only one arrested; when he doesn't show up for jury duty, he is fined without mercy; and, if on election day he goes to the parish church, they give him a completed ballot to put in the box without reading hit; if he hesitates, they give him two mil-réis [to salve] his conscience! If he protests, they threaten him; if he still doesn't give in, they have him arrested a few days later pending police investigations! And rightly so, insolent fool, why didn't you take the two mil-réis? After all, [since when are] a poor man's scruples worth more than six patacas and four vinténs?!"2 This is a conventional portrayal of nineteenth-century Brazilian citizenship and the limits imposed on popular politicization during the empire. If the "poor devil" had had any political opinions, he would have not had the means to demonstrate them, for his participation in politics was limited by the powerful who controlled the electoral process and the police apparatus.

In this text, I seek to nuance, at least somewhat, the view of imperial politics presented by Macedo. It is a preliminary sketch, inspired in part by Emmanuel Fureix's article on the mechanisms of popular politicization in France during the Bourbon Restoration and Louis Philippe's July Monarchy. Our French colleague offers us several ways to rethink the popular role in imperial Brazilian politics. French scholarship has identified a wide range of political practices that formed an "opposition public space" in these monarchical regimes with their narrow electorates restricted by income requirements. Fureix focuses on three of them: the funerals of liberal notables that became political demonstrations instead of moments of familial mourning, banquets organized by the opposition to celebrate its deputies, and political charivaris. These three rituals formed part of "an alternative political representation to the official world (that of parliamentary representation), but related to it." They formed a "new protest repertoire" in the specific context of an "expansion of the public sphere of debate" and the "simultaneous restriction of collective liberties" - in other words, the limited space for political gatherings and other forms of association. Finally, these "rites of traditional sociability" were politicized and this permitted liberal elites to gain some visibility and be delegated the mantle of sovereignty (the two connotations of representation).

Fureix calls attention to the close connections between these rituals and parliamentary politics to justify characterizing them as "modern" and, in some ways, "a third chamber," after those of the deputies and the peers. The banquet campaigns became, at certain moments, substitutes for elections. The participants in these banquets and funerals extolled liberal deputies' civic virtues, while in the charivaris "popular justice" condemned traitors to the liberal cause or certain deputies' opportunistic behavior, as well as administrative decisions judged to be arbitrary. Finally, Fureix examines the question of political sovereignty. The French electorate, around 100,000 before 1830 and 200,000 before 1848, was small, and the number participants in these demonstrations far exceeded these figures. Although it is difficult to determine their participants' social origins, Fureix argues that, during the 1830 s and 1840 s, "the rituals of protest became more 
3

BENEKE, Chris. The New, New Political History. Reviews in American History, v.33, n.3, p.314-324, set. 2005; VANDERMEER, Philip R. The New Political History: Progress and Prospects. Computers and the Humanities, n.11, p.265-278, 1978.

4

SANDERS, James E. The Vanguard of the Atlantic World: Creating Modernity, Nation, and Democracy in Nineteenth-Century Latin America. Durham: Duke University Press, 2014. p.15.

\section{5}

See, for example, POSADA-CARBÓ, Eduardo (ed.). Elections before Democracy: The History of Elections in Europe and Latin America. London: MacMillan, 1996. On elections and popular participation in post-independence Latin America, see, among others, CHAMBERS, Sarah. From Subjects to Citizens: Honor, Gender, and Politics in Arequipa, Peru, 1780-1854. University Park: Pennsylvania State University Press, 1999; WARREN, Richard A. Vagrants and Citizens: Politics and the Masses in Mexico City from Colony to Republic. Wilmington: Scholarly Resources, 2001; SANDERS, James E. Contentious Republicans: Popular Politics, Race, and Class in Nineteenth-Century Colombia. Durham: Duke University Press, 2004.

6

Developed an argument to that effect on Bahia, KRAAY, Hendrik. Muralhas da independência e liberdade do Brasil: a participação popular nas lutas políticas (Bahia, 1820-25). In: MALERBA, Jurandir (org.). A Independência brasileira: novas dimensões. Rio de Janeiro: Editora FGV, 2006. p.303-341. democratic and more radical," as exemplified by the "democratic banquets." Finally, charivaris, protest funerals, and political banquets placed "the people in the forefront of the historical stage, instituted them as sovereign," highlighted equality (to the dismay of liberal leaders who, like contemporary Brazilian Moderados (moderate liberals), had reservations about the people), and excluded violence. This centrality of the people also worked on the symbolic and imaginary levels.

Based on a variety of recent studies of popular politics at that time (to which he has contributed important works), Fureix's stimulating argument locates elements of modernity or of modern politics in unexpected places and forces us to take seriously practices that could easily be pushed to the margins of the political or the public sphere. It is part of the "new political history," which in the United States is already being called the "new new political history" to distinguish it from the "new political history" of the 1970s whose quantitative methods took advantage of the first computers. ${ }^{3}$ One of the recurring themes in this new political history is the expansion of the public sphere; not limited to intellectuals' salons, it also encompasses the "broader, more chaotic public sphere of the street." Although it is no longer innovative to argue that the popular classes had their own political views and that they were not controlled by others, it is not easy to establish the extent and significance of popular politics.

Fureix's model is one of a linear process. Politicization via the rituals that he describes is followed by the more modern politics based on universal male suffrage and on freedom of association in the second half of the century. For him, rituals of political protest are a form of "pre-democratic politicization"; they mixed older and modern forms and constituted an apprenticeship for the modern politics that gradually became established in the second half of the nineteenth century.

Reflecting on popular politics in the Brazilian empire on the basis of Fureix's insights is enriching, but it also highlights just how different Brazil was from France and how problematic it is to conceive of popular politicization as a linear process. The broad popular politicization of Brazil's independence era, as well as popular participation in imperial politics, still require deeper study, but it is easy to identify mechanisms of politicization and rites of protest that resemble those that Fureix analyzes. Restoration and July-Monarchy France are perhaps not the best points of comparison for Brazil, for the Spanish-American republics, disparaged by Brazilian monarchical rhetoric, witnessed much more radical and democratic political experiments. The Brazilian empire, moreover, conforms to the nineteenthcentury Latin American pattern of large electorates and widespread exercise of voting rights identified by students of elections. ${ }^{5}$ Instead of serving as an apprenticeship for modern politics and leading to more widespread and sustained political participation, the Brazilian episodes of popular politicization were followed by periods of reaction and repression. In this respect, too, Brazil followed the Latin American pattern.

Brazilian independence came amid a wave of popular politicization. ${ }^{6}$ However, to my knowledge, there is no scholarship that analyzes all of the specifically Brazilian popular political practices. Brazilian historiography has focused much more on movements of explicit contestation, such as the 
For representative studies, see DANTAS, Monica Duarte (org.). Revoltas, motins, revoluções: homens livres pobres e libertos no Brasil do século XIX. São Paulo: Alameda, 2011; REIS, João José. Rebelião escrava no Brasil:a história do levante dos Malês em 1835. São Paulo: Companhia das Letras, 2003.

8

See, for example, RIBEIRO, Gladys Sabina. A liberdade em construção: identidade nacional e conflitos antilusitanos no Primeiro Reinado. Rio de Janeiro: Relume-Dumará, 2002.

9

RUGENDAS, Johann Moritz. Viagem pitoresca através do Brasil. Traslated by Sérgio Milliet. São Paulo: Círculo do Livro, n.d. p.196.

10

Felisberto Caldeira Brant Pontes para Luiz José Carvalho e Mello. Salvador, 12 fev. 1824. In: BRASIL, Ministério das Relações Exteriores. Archivo diplomático da Independencia. Rio de Janeiro: Ministério das Relações Exteriores, 192225. v.2, p.6.

11

Condy Raguet to Secretary of State. Rio de Janeiro, 20 March 1826. National Archives and Records Service. United States. M-121, roll 6; and 1 Sep. 1826. Ibidem, M-121, roll 7. The Austrian minister also noted these caricatures, some of an "atrocious nature," Baron Wenzel de Mareschal to Prince Metternich. Rio de Janeiro, 28 Aug. and 18 Sep. 1826. Revista do Instituto Histórico e Geográfico Brasileiro, Rio de Janeiro, n.341, p.155 and p.158, Oct.-Dec./1983. See also PEREIRA DA SILVA, J[oão] M[anoel]. Segundo periodo do reinado de $D$. Pedro I no Brazil: narrativa histórica. Rio de Janeiro: B. L. Garnier, 1871. p.24-25, p.3637, p.38-39; MOREL, Marco. As transformações dos espaços públicos: imprensa, atores políticos e sociabilidades na cidade imperial. São Paulo: Hucitec, 2005. p.228.

12

PEREIRA DA SILVA, João Manoel. Op. Cit., p.33, p.167, p.263-264.

13

REZENDE, Francisco de Paula. Minhas recordações. Rio de Janeiro: José Olympio, 1944. p.67. revolts of free people and slaves and slave resistance, than on the politicization of the free population through means other than armed struggle. ${ }^{7}$ One tendency is to see this politicization through the lens of a search for liberty and autonomy, disconnected from party or parliamentary politics, not taking into account, for example, the Exaltado (Radical Liberal) leadership in the campaign against Pedro I. ${ }^{8}$ African and slave resistance had little to do with parliamentary and party politics, but it profoundly shaped the hopes and fears of nineteenth-century Brazilians.

Many sources suggest a high degree of politicization in Brazil at the time of independence. Johann Moritz Rugendas, who witnessed independence in Rio de Janeiro, reported that men "of all classes" conversed constantly about political questions which they followed with "much interest" and "good sense." During the more authoritarian phases of Pedro l's government, there was less space for such discussions, but this did not stop, in the critical view of Felisberto Caldeira Brant Pontes, "the directors of public opinion in the class of mulattoes and blacks, as well as among the poor and the rabble of all colors," from proposing "a hundred amendments to the draft" of the 1824 constitution when the document arrived in Bahia in February of that year. Note that the future Marquis of Barbacena could not conceive of the "class of mulattoes and blacks" as having independent political ideas and that he preferred to blame those who manipulated their "public opinion" (he also failed to comment on the nature of the proposed amendments). ${ }^{10}$ In 1826, the police could not contain the flood of seditious documents in the empire's capital and, according to the U.S. minister, "caricatures in charcoal" appeared sketched "upon the walls of white houses" with slogans like "Death to the Emperor" and "Long Live Bolivar," as well as a caricature "representing His Majesty as riding to destruction in a carriage driven by the Viscountess of Santos," his mistress. "Writing about this period, João Manuel Pereira da Silva judged that "politics was everything, everyone spoke only about politics, [all] breathed nothing but politics." According to him, the first session of parliament (1826), as well as the press freedom of late in the decade, opened a new era. ${ }^{12}$

Francisco de Paula Ferreira Rezende, from Minas Gerais, recalled that, during the Regency, "Brazil lived, so to speak, more in the public square than in the home; or, in other words, lived in a so fundamentally political environment that boys at home quickly learned how to say 'liberty' and 'homeland' [pátria]. As soon as they had learned to spell and to repeat Christian doctrine at school, they began to read and learn the empire's political constitution." ${ }^{13}$ No doubt they focused on Article 179 which specified Brazilian citizens' rights and which lent itself to different interpretations. There are many indications that its precepts of equality before the law for Brazilian citizens were known and discussed. An incident from 1829 is quite revealing: when some of the doctors in the Santa Casa de Misericórdia Hospital decided to separate patients by color - blacks and mulattoes on one side and whites on the other - one offended patient, a free black man, immediately discharged himself complaining that he "had never been anyone's slave" and "that the whites, who were there, were no better than him." His patron took the case to the liberal newspaper, Astréa, and criticized the role of Dr. Joaquim Cândido Soares de Meirelles, "who is reputed very constitutionalist." In the next issue, Meirelles defended himself. He explained that the superintendent had ordered the separation of free and slave patients, which he could accept. Some of his colleagues 
Letters from "O Inimigo das differenças de cor" and Joaquim Candido Soares de Meirelles. Astréa, Rio de Janeiro, 22 and 24 Sep. 1829.

15

CROOK, Malcolm. Elections and Democracy in France, 1789-1848. In: INNES, Joanna; PHILIP, Mark (eds.). Re-imagining Democracy in the Age of Revolutions: America, France, Britain, Ireland, 1750-1850. New York: Oxford University Press, 2013. p.93-95.

16

CARVALHO, José Murilo de. A involução da participação eleitoral no Brasil, 1821-1930. In: CARVALHO, José Murilo de; CAMPOS, Adriana Pereira (eds.). Perspectivas da cidadania no Brasil império. Rio de Janeiro: Civilização Brasileira, 2011. p.42-43.

17

TURAZZI, Maria Inez (ed.). Tipos e cenas do Brasil imperial:a Litografia Briggs na Coleção Geyer. Petrópolis: Museu Imperial, 2002, figure 22. On the political role of Spanish-American artisans, see WO0D, James A. The Society of Equality: Popular Republicanism and Democracy in Santiago de Chile, 1818-1851. Albuquerque: University of New Mexico Press, 2011; SOWELL, David. The Early Colombian Labor Movement: Artisans and Politics in Bogotá, 1832-1919. Philadelphia: Temple University Press, 1992. p.54-100; GARCÍA-BRYCE, Iñigo L. Crafting the Republic: Lima's Artisans and Nation Building in Peru, 1821-1879. Albuquerque: University of New Mexico Press, 2004.

18

See, for example, GRAHAM, Richard. Patronage and Politics in Nineteenth-Century Brazil. Stanford: Stanford University Press, 1990. p.101-121.

19

BRAZIL, Ministro da Guerra, Relatório (1848), p.30. That year the government restricted the ban to general elections, decisão 108, 6 Sep. 1848. In: Colleção das Leis do Império do Brasil. Rio de Janeiro: Typographia Nacional.

20

CARVALHO, José Murilo de. A involução da participação eleitoral no Brasil..., Op. Cit., p.50.

21

CHAGAS, Paulo Pinheiro. Teófilo Ottoni: ministro do povo. Belo Horizonte: Itatiaia, 1978. p.285-295.

22

VICUÑA MACKENNA, Benjamin. Paginas de mi diario durante tres años de viaje, 1853-1854-1855. Santiago: Universidad de Chile, [1936]. v.2, p.329.

23

Noticias provinciaes: Bahia. Correio Official, 31 March 1840.

24

SODRÉ, Nelson Werneck. História da imprensa no Brasil. 2nd ed. Rio de Janeiro: Graal, 1977. p.179200, p.265-267; ARAÚJ0, Rodrigo Cardoso Soares de. Pasquins: o submundo da imprensa na Corte imperial (1880-1883). 2009. 185f. MA Thesis in Social History. Universidade Federal do Rio de Janeiro, 2009.

25

CARVALHO, José Murilo de. D Pedro II:ser ou não ser. São Paulo: Companhia das Letras, 2007. p.84. decided to divide the patients by color, which he opposed, "saying that it was an odious division, and that we would be changing the Constitution, which does not recognize color [difference], only legal rights; if a slave as white or whiter than his master came to my department, I would put him with the slaves; and a free black, I would him with the whites, for the free are equal before the Law." ${ }^{14}$

Brazilian citizens did not just know their rights, they also exercised them fully. After independence, the Brazilian electorate was much broader than that of contemporary France, although it is difficult to determine the number of voters and electors. The income restriction of 200 mil-réis for voting was much less than the payment of 300 francs worth of direct taxes required to vote in France before 1830, when this figure was reduced to 200 francs. It is estimated that there were 100,000 French voters before 1830 and 170,000 after then, a figure that slowly grew to 240,000 during the reign of Louis-Philippe. ${ }^{15}$ Although Brazilian voters only had the right to cast ballots for the electors who selected deputies, many voted..$^{16}$ The contrast between the two countries could not have been greater. Between 1814 and 1848, there was no French counterpart to the shoemaker elector of the famous 1840 cartoon, attributed to Rafael Mendes de Carvalho (there were many in Spanish America). ${ }^{17}$ However, the dominant tendency in Brazilian scholarship is to dismiss elections: they merely served to shift power among factions of the dominant classes and the ritual of voting visibly manifested the power of local elites who led their clients to the parish church to vote. ${ }^{18}$

Brazilian citizens voted frequently, for justices of the peace, municipal councils, provincial assemblies, the chamber of deputies, officers of the National Guard, and occasionally to fill the list of three candidates for vacant senate seats. In 1848, the minister of war lamented that the prohibition of recruitment for some months before elections made it impossible to fill army and navy ranks. ${ }^{19}$ Brazilians did not just vote often, they also did so enthusiastically. As José Murilo de Carvalho reminds us, the frequent conflicts around parish churches on election days indicated "an intense involvement of voters in electoral processes and, therefore, vigorous political competition." ${ }^{20}$ In certain periods, it was even possible to organize electoral campaigns, as Teófilo Otoni and the Historical Liberals did in Rio de Janeiro in 1860. With the symbol of a white handkerchief, they were able to mobilize the capital's votes and their candidates won in all of the parishes. ${ }^{21}$

Press freedom in Brazil after 1830 impressed foreign visitors. The Chilean, Benjamin Vicuña Mackenna, was surprised at the fact that Antonio Borges da Fonseca, an old radical liberal from the 1830s, implicated in the Praieira Revolt of 1848 , was publishing a frankly republican newspaper in the capital in 1855. ${ }^{22}$ In March 1840, less than three years after the bloody repression of the Sabinada Rebellion (and before the August amnesty), Bahia was already "flooded with periodicals, some defenders of the provincial administration, others opponents, and some of them extreme opponents." ${ }^{23}$ In the 1830s, from 1848 to the early 1850s, and in the 1880 s there were waves of radical periodicals, but it is difficult to determine their circulation..$^{24}$ Some historians have gone so far as to suggest that press freedom was greater under the empire than during the Republic. ${ }^{25}$

Frequent elections, assiduous newspaper reading, debates in public squares about political questions, knowledge of constitutional articles the Brazil of the first decades of the empire looks like a highly-politicized 
SANDERS, James E. The Vanguard of the Atlantic World..., Op. Cit., p.16, p.18-19.

27

MOREL, Marco. As transformações dos espaços públicos... Op. Cit., p.47.

28

For an analyis of radical liberal symbols, see KRAAY, Hendrik. Days of National Festivity in Rio de Janeiro, Brazil, 1823-1889. Stanford: Stanford University Press, 2013. p.64-71.

29

On the political context, see MONTEIRO, Tobias. História do Império: o Primeiro Reinado. Belo Horizonte: Itatiaia; São Paulo: Ed. da Universidade de São Paulo, 1982. v.2, p.186-187; BARMAN, Roderick J. Brazil: The Forging of a Nation, 1798-1852. Stanford: Stanford University Press, 1988. p.157-158.

30

DIARIO MERCANTIL OU NOVO JORNAL DO COMMERCIO. 10 Nov. 1830; CORREIO MERCANTIL. 11 Nov. 1830.

31

AURORA FLUMINENSE. Rio de Janeiro, 10 Nov. 1830; NOVA LUZ BRASILEIRA. Rio de Janeiro, 12 Nov. 1830; William H. D. C. Wright to Secretary of State. Rio de Janeiro, 10 Nov. 1830. National Archives and Records Service. United States. M-121, rolo 9.

32

VOZ FLUMINENSE. Rio de Janeiro, 18 Nov. 1830. 33

ASTRÉA. Rio de Janeiro, n.18, 20 and 23 Nov. 1830; AURORA FLUMINENSE. Rio de Janeiro, 19 and 22 Nov. 1830. Coincidentally, the last day of fusion, 20 November, was also the day on which Libero Badaró was mortally wounded in São Paulo (see Cláudia Rodrigues's article in this issue). country, one already quite "modern" if we accept the definition proposed by James E. Sanders in his analysis of American republican modernity. This ideology, widespread in Spanish America and predominant during the midcentury liberal regimes, rested on understandings of progress on the basis of the "greatest extension possible of liberty and equality to all citizens." ${ }^{26}$ Slavery and monarchy make it difficult to characterize the Brazilian empire as "modern," but by the standards of contemporary constitutional monarchies, Brazil was not the least in terms of the political rights that it granted its citizens. Not surprisingly, Pedro I, although condemned in Brazil for his authoritarian tendencies, was considered "among the most modern of constitutional monarchs" when he returned to Europe in 1831. ${ }^{27}$

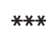

In this Brazilian context, it is easy to identify examples of politicization similar to those analyzed by Fureix, which share the common characteristic of mobilizing those excluded from formal politics to pressure the government, parties, or politicians. The radical liberal campaign against Pedro I, with its straw hats, coffee and croton leaves, the tope nacional (a badge with the slogan "Independence or Death!"), songs, disturbances in the theater, special cheers ("Long Live Pedro I So Long as He Is Constitutional!" instead of "Long Live Pedro I!"), among other rituals and symbols, was a moment of widespread political mobilization that went beyond the bounds of parliament, but was closely connected to it. ${ }^{28}$

The November 1830 political crisis, less well-known than episodes like the March 1831 Noite das Garrafadas (Night of the Bottle Blows) riots, reveals the close connection between parliament and street politics. The fusion of the senate and the chamber of deputies to vote on the budget had never before taken place and was controversial. Prescribed by article 61 of the constitution when amendments to a bill voted by one chamber were rejected by the other, fusion was supported by liberals and radical liberals because it was the constitutional procedure and because it demonstrated the chamber of deputies' superiority. Deputies had voted for a budget that would restrict the government's freedom to act and had rejected contrary amendments supported by the senate..$^{29}$ When the delegation from the chamber that had taken the request for fusion to the senate was returning, an "immense [group of] the people" detached the mules from the coach and towed the deputies back to their chamber, giving "the most fervent cheers to the Constitution, to the Emperor, and to the illustrious members of the delegation (José Lino Coutinho, Bernardo Pereira de Vasconcelos and Antonio Paulino Limpo de Abreu)..$^{30}$ According to the Aurora Fluminense and A Nova Luz Brasileira, those who accompanied the deputies were not just members of the people [povo] but "citizens." The U.S. minister did not know whether the demonstrators were "respectable." ${ }^{31}$

During the four days of joint legislative sessions, large crowds gathered around the senate house; the editor of Voz Fluminense judged them to be citizens and took a jab at pro-government's periodicals ("don't think, Imparcial and Moderador, that they are moleques" [a pejorative term for black men and boys]). ${ }^{32}$ According to Astréa and Aurora Fluminense, more than 2,000 people respectfully followed the debates and hailed deputies with flowers and cheers to the constitution and to the assembly at the end of each day. ${ }^{33} \mathrm{O}$ Brasileiro Imparcial avoided calling them moleques but 


\section{4}

O BRASILEIRO IMPARCIAL. Rio de Janeiro, 23 Nov. 1830. For a rebuttal of this article, see AURORA FLUMINENSE. Rio de Janeiro, 26 Nov. 1830.

35

Triunfo da Opinião Publica. Nova Luz Brasileira, Rio de janeiro, 30 Nov. 1830.

36

The Sabinada is a classic example, KRAAY, Hendrik. Tão assustadora quanto inesperada: a Sabinada baiana, 1837-1838. In: DANTAS, Monica Duarte (org.). Op. Cit., p.269.

37

Justice of the Peace to President. Santo Amaro, 14 Feb. 1840. Arquivo Público do Estado da Bahia. Salvador, Brasil. m.2583. The council secretary reported in 1831 that he had challenged the slave, who retorted that "he was a citizen like me," hitting the table with a dagger, SEIXAS, João Lourenço de Athaide. Exposição dos acontecimentos da Villa de S.to Amaro da Purificação em abril de 1831. Arquivo Público do Estado da Bahia. Salvador, Brasil. m.2852. João José Reis cites this incident based on this source, REIS, João José. Rebelião escrava no Brasil. Op. Cit., p.66.

38

On this concept, see TILLY, Charles. Contentious Performances. Cambridge: Cambridge University Press, 2008. p.15-17.

39

Observações de hum viajante q' passou pela B.a p.a hum seo amigo no Rio. Arquivo Histórico do Museu Imperial. Petrópolis, Brasil. IIPOB-04.09.1827 Hor.c 1-20.

40

JORNAL DO COMMERCIO. Rio de Janeiro, 9 Sep. 1831.

41

João Loureiro to Manuel José Maria da Costa e Sá. Rio de Janeiro, 15 0ct. 1831. Revista do Instituto Histórico e Geográfico Brasileiro, v.76, n.2, p.379, 1914.

42

Francisco Joaquim Alvares Br.co Moniz Barretto to Pedro I. Salvador, 11 July 1830. Arquivo Histórico do Museu Imperial. Petrópolis, Brasil. II-POB-08.03.1830. Bar.c. On Barata's reception on 17 Dec. 1830. See: MOREL, Marco. Cipriano Barata na sentinela da liberdade. Salvador: Academia das Letras da Bahia, 2001. p.242-243.

43

FUREIX, Emmanuel. La France des larmes: deuils politiques à l'âge romantique (1814-1840). Seyssel: Champ Vallon, 2009.

44

REIS, João José. A morte é uma festa: ritos fúnebres e revolta popular no Brasil do século XIX. São Paulo: Companhia das Letras, 1991. p.165-166. lamented that "a large gathering of radical liberals ... with the insignia of a coffee leaf on their breasts" prevented the free movement of deputies and senators. They "made rude remarks," "one madman" shouted into the "venerable Viscount of Cairu's" ear, and a deputy was kicked in the shins. ${ }^{34}$ Nova Luz Brasileira concluded by judging the episode a great "triumph of public opinion." 35 While there were very different assessments of this incident, all newspapers concurred that few were indifferent to parliamentary politics and that public opinion had to be taken into account. In this way, like their French counterparts, Brazilian liberals and radical liberals manifested popular sovereignty through public demonstrations.

Public opinion also manifested itself through other, less "modern" means. The urban revolts of the 1820s and 1830s in the North of the country had a repertoire of rituals that focused on popular sovereignty embodied in city councils: calling the people together by ringing the bell; writing an act signed by many and, sometimes, the later correction or erasure of it. ${ }^{36}$ It is in this political culture that José Inácio's actions in Santo Amaro gain their full significance: a crioulo (Brazilian-born black), apparently freed in 1840, he had earned the nickname of "Deputy" for his bold political act in 1831, when he was still a slave. During an anti-Portuguese riot, he went to the council chambers, sat beside other patriots, "and stabbed a dagger into the table, saying 'I'm a Brazilian Citizen.'37

Banquets formed part of this repertoire of political contestation. ${ }^{38}$ The Bahian radical liberals who, in 1827, invented the form of commemorating the Portuguese defeat of 1823 (the Dois de Julho festival) with a parade into the city that recalled the march of the Exército Pacificador (Pacification Army), organized "a church celebration, a parade, dinners, illuminations, and speeches of the most violent nature." ${ }^{39}$ On 7 September 1831, Moderados celebrated Independence with "private banquets" in which they "raised very patriotic toasts in honor of this memorable day to Independence; to Liberty; to the Brazilian monarch, our angel of peace; to the National Congress; to the Regency; [and] to the Fraternal Union of all Brazilians." 40 The Caramurus (absolutists) were not far behind: on 12 0ctober of this year, they held "private dinners" with "cheers to Pedro I" (that day was his birthday)..$^{41}$ There are no indications of the participants' social origins, nor is it known how these banquets were paid for, but the competing civic rituals and political demonstrations of these years relied on public subscriptions. In July 1830, Francisco Joaquim Álvares Branco Moniz Barreto lamented that Bahian "liberals" were "working on a subscription for the arrival of [Cipriano José] Barata [de Almeida]"; they planned to receive the liberal journalist, recently-freed from prison in the capital, with "music, arches and a Te-Deum mass, and illuminations." 42

As far as political funerals - the topic of Fureix's book ${ }^{43}$ - go, to my knowledge there are no Brazilian counterparts (but see the article by Cláudia Rodrigues in this issue). We can recall the symbolic funeral of the justice of the peace of Cachoeira (Bahia) held by about eighty people in 1829. The investigation revealed the participation of radical liberals and future federalist rebels like Miguel Guanaes Mineiro who celebrated the absolutist justice's departure to the sounds of music, shouts against corcundas (hunchbacks, a nickname for absolutists), rockets, and ringing the church bell. ${ }^{44}$ While structured like a funeral, the incident has all the marks of a charivari, a custom unknown in Brazil. Fureix's charivaris or political serenades - the adaptation of an ancient rural European custom that 
45

PRIORE, Mary del. A serração da velha: charivari, morte e festa no mundo luso-brasileiro. In: JANCSÓ, István; KANTOR, Iris (eds.). Festa: cultura e sociabilidade na América portuguesa. São Paulo: Hucitec : Edusp : Fapesp, Imprensa Oficial, 2001. v.1, p.279-297.

CÂMARA CASCUDO, Luís da. Dicionário do folclore brasileiro. 9th ed. São Paulo: Ediouro, s.d. p.821.

47

SANTOS, Lidia Rafaela Nascimento. Das festas aos botequins: organização e controle dos divertimentos no Recife (1822-1850). 2011. 144f. MA Thesis. Centro de Filosofia e Ciências Humanas, Universidade Federal de Pernambuco, 2011. p.43.

48

Justice of the Peace to President. Maragogipe, 4 Aug. 1839. Arquivo Público do Estado da Bahia. Salvador, Bahia. m.2471.

49

REZENDE, Francisco de Paula. Op. Cit., p.228; LISBOA, João Francisco. Jornal de Timon: partidos e eleições no Maranhão. José Murilo de Carvalho (org.). São Paulo: Companhia das Letras, 1995, p.189.

50

A LUZ BRASILEIRA. Rio de Janeiro, 24 March 1830; AURORA FLUMINENSE. Rio de Janeiro, 22 March 1830; ASTRÉA. Rio de Janeiro, 27 March 1830.

51

0 BRASILEIRO IMPARCIAL. Rio de Janeiro, 27 March 1830; ASTRÉA. Rio de Janeiro, 27 March 1830; AURORA FLUMINENSE. Rio de Janeiro, 29 March 1830; JORNAL DO COMMERCIO. Rio de Janeiro, 27 March 1830 normally denounced elderly widows' second marriages to young women - have no counterpart in Brazil. According to Mary del Priore, the serração da velha (sawing of the old woman, a rowdy festival normally held in midLent) had all the elements of the European charivari, but its political use is rarely documented. ${ }^{45}$ Luís da Câmara Cascudo notes that, "on occasion, the Serração da Velha was done outside of Lent with political intentions, a demonstration of discontent at the door of the house of a fallen [political] boss or someone defeated in elections." ${ }^{46}$ The Olinda justice of the peace who tried to prevent an 1834 serração - prohibited by the 1831 municipal bylaws - did not allege any political motives for the gathering of a "considerable number [of men] without fear, and without respect for the laws and the authorities" but, in those turbulent Regency years, the distance between a prohibited celebration and a political demonstration was not great (or, at least, this is what authorities feared). ${ }^{47}$ Another demonstration against an authority figure considered abusive recalls Câmara Cascudo's description: the Maragogipe justice of the peace's recruitment efforts prompted a celebration when he stepped down in 1839 and the justice lamented that the youth had gone out "playing guitars, singing, and insulting [him] in the streets where they wander with impunity." ${ }^{48}$ The postSabinada repression included mass recruitment of the defeated rebels and, therefore, it is possible that this "charivari" against the official responsible for the arrest of recruits had political connotations.

In the civic rituals that I have been studying for many years - a theme dear to the new political history - there were in certain periods waves of popular festivals (that is, not organized by the government), frequently liked to political mobilizations. Rezende recalled how Minas Gerais civic celebrations were party manifestations in the 1830s and João Francisco Lisboa observed the same for Maranhão. ${ }^{49}$ A subtle innovation in this direction was the first civic festival outside of government control in Rio de Janeiro, the celebration of the Constitution organized by Exaltados on 25 March 1830. They resolved to celebrate "spontaneously" the sixth anniversary of the oath to the constitution to demonstrate their loyalty to the "political system that governs us on paper, but not in practice." ${ }^{50}$ After the official commemorations (since 1826, it had been a day of national festivity), a crowd gathered at Constitution Square (in front of the theater) to cheer the monarch; led by brass bands, the patriots dispersed to their parishes, singing anthems and giving cheers to the "objects of our public veneration," among them the Constitution, "the great Pedro, constitutional emperor," Independence, and parliament. Many ladies watched the demonstration from the balconies of their houses, waving white handkerchiefs and tossing flowers on the participants. The majority of residents put lamps or candles in their windows, even though the authorities had not invited the population to illuminate the city. ${ }^{51}$ For the first time during Pedro I's reign, a civic festival had taken place without the government's initiative; it was a ritual in which the Old Regime's forms of celebration were used to commemorate a modern institution - the constitution.

Elsewhere I have analyzed the press debate about the significance of this demonstration. Conservative journalists lamented the presence of blacks and mulattoes among the Exaltados, the cheers to liberty in a slave country, and the insults directed at the owners of unilluminated houses. Exaltados highlighted the celebration's orderly nature and the support for the constitution. Evaristo da Veiga hailed the participations, raised on the 
AURORA FLUMINENSE. Rio de Janeiro, 29 March 1830. See also KRAAY, Hendrik. Days of National Festivity in Rio de Janeiro..., Op. Cit., p.55-56; and Idem. Nação, Estado e política popular no Rio de Janeiro: rituais cívicos depois da Independência. In: PAMPLONA, Marco; DOYLE, Don H. (eds.). Nacionalismo no Novo Mundo: a formação de Estados-Nação no século XIX. Rio de Janeiro: Record, 2008. p.336-339.

53

KRAAY, Hendrik. Days of National Festivity in Rio de Janeiro..., Op. Cit., p.132-134.

54

ASTRÉA. Rio de Janeiro, 7 Sep. 1830; MOREL, Marco. Cipriano Barata na sentinela da liberdade..., Op. Cit., p.257.

55

TITARA, Ladislau dos Santos. Elogio. In: Obras poeticas dedicadas a mocidade brasileira. Salvador: Typ. Imperial e Nacional, 1835. v.3, p.93, p.97.

56

O BRASILEIRO IMPARCIAL. Rio de Janeiro, 24 July 1830.

57

AURORA FLUMINENSE. Rio de Janeiro, 1 Sep. 1830.

58

This is the central argument of KRAAY, Hendrik. Days of National Festivity in Rio de Janeiro..., Op. Cit.

59

SABATO, Hilda. The Many and the Few: Political Participation in Republican Buenos Aires. Stanford: Stanford University Press, 2001; FORMENT, Carlos A. Democracy in Latin America, 1760-1900. Vol.1: Civic Selfhood and Public Life in Mexico and Peru. Chicago: University of Chicago Press, 2003.

60

JESUS, Ronaldo Pereira de. Associativismo no Brasil do século XIX: repertório crítico dos registros de sociedades no Conselho de Estado (18601889). Locus, v.13, n.1, p.144-170, Jan.-June 2007; VISCARDI, Cláudia Maria Ribeiro. Experiências da prática associativa no Brasil, 1860-1880. Topoi, v.9, n.16, p.117-136, Jan.-June 2008.

61

MOREIRA DE AZEVED0, Manuel Duarte. Sociedades fundadas no Brasil desde os tempos coloniaes até o começo do actual reinado. Revista do Instituto Histórico e Geográfico Brasileiro. Rio de Janeiro, Rio de Janeiro, v.48, n.2, p.294, 1885.

62

MOREL, Marco. 0 abade Grégoire, o Haiti e o Brasil: repercussões no raiar do século XIX. Almanack Braziliense, n.2, p.87-89, nov. 2005.

63

Associação Nacional dos Artistas. Correio da Tarde, 10 Sep. 1857; KRAAY, Hendrik. Days of National Festivity in Rio de Janeiro..., Op. Cit., p.185-186. For a preliminary analysis of these societies, see KRAAY, Hendrik. "Sejamos brasileiros no dia da nossa nacionalidade": comemorações da Independência no Rio de Janeiro. Topoi, v.8, n.14, p.9-36, Jan.-June 2007. "milk of the new doctrines ... who will always know how to maintain the human race's dignity [and] the rights of their country." ${ }^{52}$

There were other similar episodes in which the opposition organized popular civic celebrations, such as 7 September 1848, also a day of municipal elections, ${ }^{53}$ or the notable role of Exaltados in the invention of the Dois de Julho festival in the late 1820s. In 1830's celebration, several thousand men, "the majority of color," according to the French consul, accompanied the militia battalions in the great parade from Lapinha to Salvador's city center. $O$ Escudo da Constituição described the festival and the satisfaction of the "true constitutionalists" with the orderly demonstration. ${ }^{54}$ The poet, Ladislau dos Santos Titara, hailed Bahia which "Will be the first in firmly protecting / The constitution, independence," and condemned the "cruel despots" and "base slaves / Incapable of demonstrating Love for the Pátria!" ${ }^{55}$ In the capital, Astréa published 0 Escudo's report on 7 September (no doubt to encourage the celebration of independence), but 0 Brasileiro Imparcial had already lamented that the Bahian "Exaltados, who respect nothing," had obliged everyone to contribute to the popular subscription for the festival, insulting those who did not wish to contribute with epithets of "maroto, chumbeiro [pejorative terms for Portuguese], recolonizer." 56 Bahians' "patriotism" filled Evaristo da Veiga with "true joy." ${ }^{57}$ Both Imparcial's editor and the future spokesman for moderate liberals recognized the political meaning of this Dois de Julho festival. In short, civic celebrations provoked debates about the composition of the people and the nation, about citizenship, and about imperial institutions (the monarchy and the constitution, celebrated respectively on the emperor's birthday and on 25 March). These were ritualized ways of doing politics that went beyond the parliamentary realm or formal politics, but still had close connections to the empire's political institutions. ${ }^{58}$

Associational life, whose importance for politicization in Spanish America has been identified by Hilda Sabato and Carlos Forment, ${ }^{59}$ has been little studied in Brazil. The dominant view remains that Brazilians were little given to associational life. It is difficult to determine the extent of associational life in Brazil before the 1860 law that regulated the foundation of societies and obliged them to submit their statues to the Council of State. ${ }^{60}$ Nevertheless, there are indications of a wave of associations in the 1830s: in 1884, Manuel Duarte Moreira de Azevedo wrote that "right after Pedro I's abdication, the spirit of association developed" and he counted more than one hundred societies created at this time. ${ }^{61}$ Even the accusations of the existence of a Gregorian Society whose black membership planned to massacre whites are an indication of this tendency. ${ }^{62}$ The wave of patriotic societies founded in the capital in the second half of the 1850 s (twenty of them were noted in the press before 1864) is another indication of Brazilian society's politicization. Organized to celebrate the 7 September (Independence Day), these societies mobilized artisans, students, and neighborhood residences. They were not exclusively celebratory: during its formal meeting on 7 September 1857, the Associação Nacional dos Artistas (National Association of Artisans) honored the Pernambucan deputy, Francisco Carlos Brandão, for his efforts to "better the state of the poor classes, the country's needy classes"; among other bills, he had presented one that would require all stores, factories, and workshops to close on Sundays and saints' days. ${ }^{63}$ The Associação's political activities were much more closely connected to parliamentary politics than those of 
64

MAC CORD, Marcelo. Artífices da cidadania: mutualismo, educação e trabalho no Recife oitocentista. Campinas: Editora da Unicamp, 2012

65

W00D, James A. Op. Cit., p.187-223.
66

MATTOS, Ilmar Rohloff de. 0 tempo saquarema. São Paulo Hucitec, 1987.

67

CARVALHO, José Murilo de. A involução da participação eleitoral no Brasil..., 0p. Cit., p.47-48.

68

ALONSO, Angela. Associativismo avant la lettre - as sociedades pela abolição da escravidão no Brasil oitocentista. Sociologas, v.13, n.28, p.193, Sep.-Dec. 2011. On these elements of the abolition movement, see SILVA, Eduardo. As camélias de Leblon e a abolição da escravatura. São Paulo: Companhia das Letras, 2003; KITTLESON, Roger A. Women and Notions of Womanhood in Brazilian Abolitionism. In: SCULLY, Pamela; PATON, Diana (eds.). Gender and Slave Emancipation in the Atlantic World. Durham: Duke University Press, 2005. p.99-120; CASTILHO, Celso Thomas. Performing Abolition, Enacting Citizenship: The Social Construction of Political Rights in 1880s Recife, Brazil. Hispanic American Historical Review, v.93, n.3, p.377-410, Aug. 2013. For the connections between the movement and the political system, see NEEDELL, Jeffrey D. Brazilian Abolitionism, Its Historiography, and the Uses of Political History. Journal of Latin American Studies, v.42, n.2, p.231-61, May 2010.

69

AZEVEDO, Célia Maria Marinho de. Onda negra, medo branco: o negro livro no imaginário das elites - século XIX. Rio de Janeiro: Paz e Terra, 1987; ALBUQUERQUE, Wlamyra R. de. 0 jogo da dissimulação: abolição e cidadania negra no Brasil. São Paulo: Companhia das Letras, 2009; CARVALHO, José Murilo de. Os bestializados: o Rio de Janeiro e a República que não foi. São Paulo: Companhia das Letras, 1987. the Sociedade das Artes Mecâncias (Society of Mechanical Arts), founded in 1841 in Recife, whose leadership linked themselves to Pernambucan patronage networks. ${ }^{64}$ It appears that the political activities of the Brazilian artisan societies did not reach the level or radicalization of some of their Spanish-American counterparts, ${ }^{65}$ but they offer another way to approach Brazilian popular politicization.

In the struggles for independence, in the Exaltado campaign against Pedro I, in 1848-50, as well is in many other lesser or greater episodes, divisions in the Brazilian political elite opened up spaces for more visible popular political participation, but politicization did not depend on divisions in the dominant classes. Brazilians were active political subjects. They voted, read newspapers (or heard them read), participated in civic rituals and other political demonstrations, and gathered in societies and associations.

It is, however, difficult to argue that the elements of popular politicization analyzed up to this point, with all of their "pre-democratic" features, as Fureix would put it, and with their modern elements, led to a more profound politicization in the second half of the nineteenth century. The Regresso, the repression of popular revolts and those of regional elites, the construction of the "Tempo Saquarema"66 and, finally, the 1881 reduction of the electorate closed the spaces for popular politics and created a political context very similar to that of the period in France analyzed by Fureix. The number of Brazilian voters in the 1880s (about 100,000, a tenth of the number of voters in the 1870s) was the same as the number of French voters before $1830 .{ }^{67}$

At this time, Brazil witnessed a large popular campaign that mobilized broad sectors of society excluded from the political world, but in close connection to parliamentary activities: the abolition movement. With its symbols (the Leblon camellias), rituals (meetings, theater galas in benefit of the cause; the public freeing of slaves, mostly women; campaigns to free city blocks of slavery; campaigns on behalf of abolitionist candidates), hundreds of associations and societies, bazaars, and the participation of a large part of the population denied the vote by the 1881 law, the abolition movement brought a new political repertoire to Brazil. According to Ângela Alonso, abolitionism "inaugurated popular politics in Brazil" and "was the first great social movement in Brazil." ${ }^{88}$ The primacy of abolitionism's popular politics could be debated, but there is no doubt that abolitionism was a large social and political movement.

After the celebrations of 13 May (slavery was officially abolished on that day in 1888) came the reactions: the refusal to consider other reforms, the repression of black mobilization and the racialization of rhetoric about society, and the dismissal of the people as unworthy; finally the republic with few significant reforms and its population "reduced to the status of dumb beasts [bestializado]." ${ }^{69}$ Several factors shaped the abolitionist movement and prevented its continuation beyond the immediate context. All wanted the end of slavery; as long as the abolitionist movement operated within the legal framework and respected property rights, it could be accepted by all. Those who opposed the abolitionists were concerned about the maintenance of order and wanted to be indemnified for the loss of slave property. They did not seek to perpetuate slavery indefinitely. 
70

SANDERS, James E. The Vanguard of the Atlantic World..., Op. Cit., p.176-224.

71

KRAAY, Hendrik. Days of National Festivity in Rio de Janeiro..., Op. Cit., p.56; MOREL, Marco. As transformações dos espaços públicos..., $0 p$. Cit., p.161. The authorities responsible for this decision were harshly criticized by the radical press; see, for example, NOVA LUZ BRASILEIRA. Rio de Janeiro, 16 Nov. 1830.
They also did not want mobilized citizens, active, conscious of their rights, demanding. While the empire opened spaces for popular political participation, it always closed them when this participation appeared to threaten order. The same took place in Spanish America. The conservative regimes of the century's last decades, like the Regeneration in Colombia or the Porfiriato in Mexico, put an end to the politicization of the era of "American republican modernity." Their understanding of liberalism was primarily economic, and left no space for popular political participation. ${ }^{70}$

This pattern of reactions against popular political mobilizations also worked on the individual and ritual levels. His insistence on the equality of citizens of all colors led to accusations that Meirelles was plotting the death of whites in 1831's alleged Gregorian Society. In the heady days of 1831, the slave José Inácio could imagine himself a citizen. We only know, however, of his nickname (Deputy) because he was forcibly recruited into the army in 1840, at a time when the authorities in Santo Amaro felt themselves strong enough to get rid of him. Police authorization was denied to the Exaltados who wanted to celebrate 7 September 1830 in Rio de Janeiro's Passeio Público (Public Park) as a continuation of their success of 25 March. ${ }^{71}$ The Dois de Julho festival was repressed after the Sabinada (but revived in the 1840s). In popular politics, like all politics, the stakes are high. 